\title{
Librarian Acceptance on the Resource Description and Access (RDA)
}

Abd Latif Abdul Rahman, Zati Atiqah Mohamad Tanuri, Zuraidah Arif, Tengku Rafidatul Akma Tengku Razali, Ahmad Sufi Alawi Idris, Mohd Zool Hilmie Mohammed Sawal \& Siti Nur Shahira Dahari

To Link this Article: http://dx.doi.org/10.6007/IJARBSS/v11-i12/11812 $\quad$ DOI:10.6007/IJARBSS/v11-i12/11812

Received: 05 October 2021, Revised: 07 November 2021, Accepted: 22 November 2021

Published Online: 09 December 2021

In-Text Citation: (Rahman et al., 2021)

To Cite this Article: Rahman, A. L. A., Tanuri, Z. A. M., Arif, Z., Razali, T. R. A. T., Idris, A. S. A., Sawal, M. Z. H. M., \& Dahari, S. N. S. (2021). Librarian Acceptance on the Resource Description and Access (RDA). International Journal of Academic Research in Business and Social Sciences, 11(12), 709-722.

\section{Copyright: (c) 2021 The Author(s)}

Published by Human Resource Management Academic Research Society (www.hrmars.com) This article is published under the Creative Commons Attribution (CC BY 4.0) license. Anyone may reproduce, distribute, translate and create derivative works of this article (for both commercial and non0-commercial purposes), subject to full attribution to the original publication and authors. The full terms of this license may be seen

at: $\underline{\text { http://creativecommons.org/licences/by/4.0/legalcode }}$

Vol. 11, No. 12, 2021, Pg. $709-722$

Full Terms \& Conditions of access and use can be found at http://hrmars.com/index.php/pages/detail/publication-ethics 


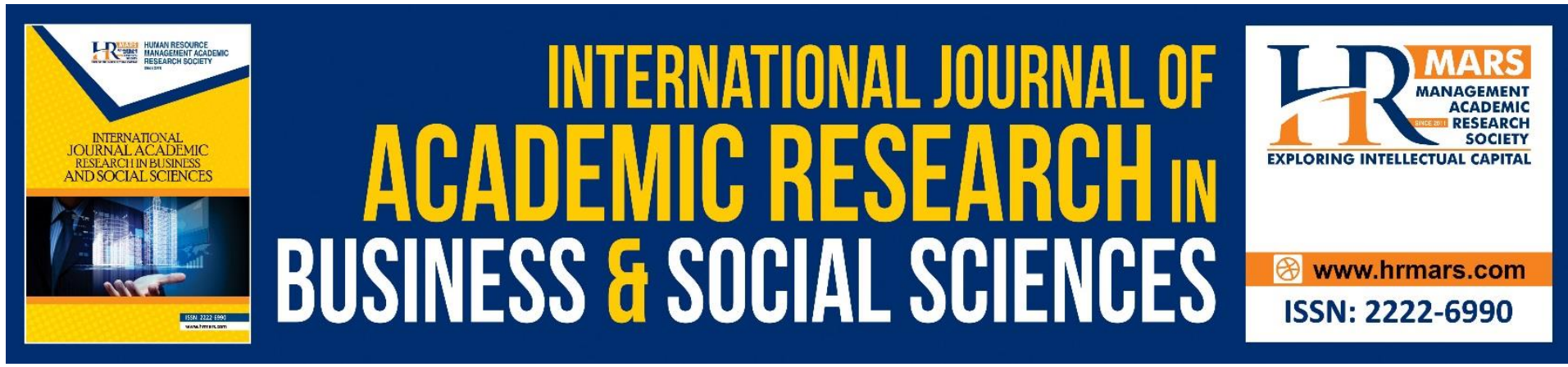

\title{
Librarian Acceptance on the Resource Description and Access (RDA)
}

\author{
Abd Latif Abdul Rahman, Zati Atiqah Mohamad Tanuri, \\ Zuraidah Arif, Tengku Rafidatul Akma Tengku Razali, Ahmad \\ Sufi Alawi Idris, Mohd Zool Hilmie Mohammed Sawal \& Siti Nur \\ Shahira Dahari \\ Faculty of Information Management, Universiti Teknologi MARA Kedah \\ Malaysia
}

Email: ablatif@uitm.edu.my,zatiatiqah@uitm.edu.my,zuraidah_arif@uitm.edu.my,

tgrafidatul@uitm.edu.my, sufiidris@uitm.edu.my, zoolhilmie@uitm.edu.my,

nurshahira@uitm.edu.my

\begin{abstract}
Technology advancement has significantly impacted and changed the cataloguing standards towards Resources Description and Access (RDA). RDA is designed for the networked digital environment based on a theoretical framework that defines the shape, structure and content of the new standard. This will enable library catalog users to find, identify, select and obtain resources according to their information needs. Although RDA had been tested and implement in the various library setting like Library of Congress and National Agricultural Library. However, the implementation of the new cataloging standard will involve a big challenge because the acceptance of the librarians in Malaysia are varies. Thus elements of motivations will greatly drive the successful of this implementation. Thus, this study was conducted to examine the understanding of the librarians towards acceptance of RDA practices from motivational aspects and identify which factors influence librarian acceptance towards RDA. A self-administrated questionnaire was distributed and collected from librarians in NLM as a leading agency in the implementation of RDA in Malaysia. A total of 24 valid questionnaires were received by the end of data collection's period. SmartPLS software was used to evaluate the relationships among the constructs of the research model by conducting partial least squares (PLS) analysis because it allows to analyze data during the early stage of theory development. The results show that the second-order construct of intrinsic motivation has significant effect on librarian intention to accept RDA while the second order construct of extrinsic motivation does not. The future implications and conclusion are discussed in abstract.
\end{abstract}

Keywords: Intrinsic Motivation, Extrinsic Motivation, Intention to Accept, Resource Description and Access (RDA), Motivation. 


\section{Introduction}

Technology advancement is gaining a great deal of attention among Malaysian citizens especially young individuals. Technology has significantly impacted and changed the context and the way people live in recent years, particularly in the terms of information searching, information retrieving and information sharing as (Kiorgaard \& Kartus, 2005) mentioned that the development of the new media especially internet resources and the evolution of the catalogue and large database. Hence, the changed in the information environment had changed the cataloguing standards towards Resources Description and Access (RDA) in 2008 from Anglo-American Cataloguing Rules 2 (AACR2). RDA is designed for the networked digital environment. RDA is designed based on a theoretical framework that defines the shape, structure and content of the new standard (Oliver, 2010). There are two conceptual models that set the foundation of RDA: (1) Functional Requirements for Bibliographic Records (FRBR) and (2) Functional Requirements for Authority Data (FRAD). RDA compliance will enable library catalog users to find, identify, select and obtain resources according to their information needs.

The implementation of RDA in Malaysia still at the beginning stage where National Library of Malaysia (NLM), who is a leading agency in the implementation of RDA in Malaysia send two NLM's librarian to National Library of Australia to study the implementation of RDA standards in 2013, published a Guidebook on RDA implementation in Malaysia on 3rd April 2014 and conducted Training of Trainers Workshop to share the knowledge and expertise on RDA (Jyoon \& Zakaria, 2015). Although RDA had been tested and implement in the various library setting like Library of Congress, National Agricultural Library, the National Library of Medicine, USA; The British Library; Library and Archives of Canada; National Library Board of Singapore; and the National Library of Australia, the implementation of the RDA in 12,351 libraries (Abu Bakar \& Jyoon, 2012) in Malaysia will involve a big challenge because the acceptance of the librarians in Malaysia are varies. Some of them will accept the RDA meanwhile majority of them are reluctant to adopt the new cataloging standard. An earlier survey by phone called across state libraries and government university libraries had been done in late 2014 to gain information regarding the RDA implementation in Malaysia's libraries; however there is no other libraries had implemented it except NLM.

However, the implementation of the new cataloging standard will involve a big challenge because the acceptance of the librarians in Malaysia are varies (Tanuri ei, 2017). Miksa (2009) pointed out that the change in cataloging rules is much needed but might not be acceptable by all. Some of them will accept the RDA meanwhile majority of them are reluctant to adopt the new cataloging standard. Because on that, there is an urgent need to understand the acceptance of the RDA in Malaysia especially from the motivation aspect (Slot \& Opree, 2021) of the librarian, so that the new approaches can be implement for the benefit of the library in Malaysia. The both intrinsic motivation and extrinsic motivation was important to understand as driving success of the RDA acceptance (Tanuri et al., 2017). This study aims to formulate a new model of librarian acceptance new cataloging standard model from motivational aspects and identify which factors influence librarian acceptance towards RDA.

\section{Literature Review}

This research combined the understanding of the intention to accept and use the new standard, system and technology from the TAM, UTAUT and TPB model. However the variables involved are treated from the motivational aspects, as Sánchez \& Hueros (2010); Dickerson (2013); Agrifoglio, Black, \& Metallo (2010); Lee, Cheung, \& Chen (2005) treated 
variables in TAM as a motivational factors while (Ursula, Gohar, Junghoon, \& Jae, 2011) treated variables in UTAUT as motivational factors. Hence, The UTAUT, TPB and motivation theory were used in this research with some alteration.

(Vankatesh et al., 2003) realized the disparate nature of multiple theories being applied to understanding how users accept technology and establishing UTAUT from the eight theories 1)Theory of Reasoned Action (TRA) 2) Model of PC Utilization (MPCU) 3) Motivation Model (MM) 4) Combined TAM and TPB (C-TAM-TPB) 5) Technology Acceptance Model (TAM2) 6) Theory of Planned Behavior (TPB) 7) Innovation Diffusion Theory (IDT) 8) Social Cognitive Theory (SCT). Seven constructs appeared to be significant direct determinants of intention or usage models where four of it: performance expectancy, effort expectancy, social influence, and facilitating conditions play a significant role as direct determinants of user acceptance and usage behavior.

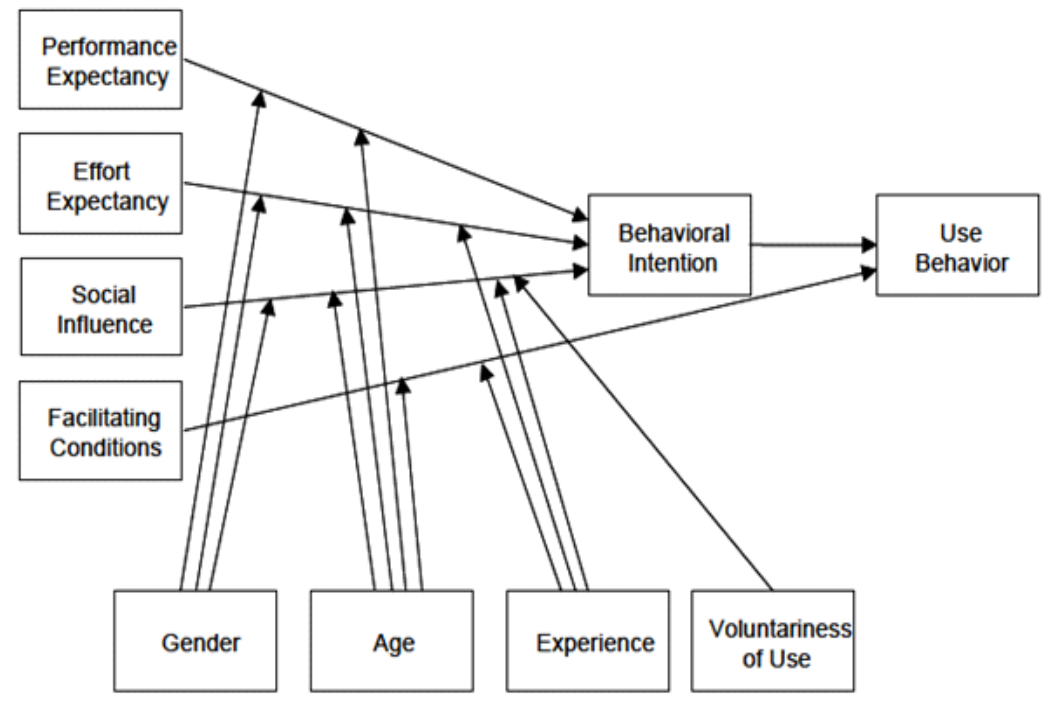

Figure 1: Unified Theory of Acceptance and Use of Technology (UTAUT) (Ventakesh et al., 2003)

TPB was developed by (Ajzen, 1991) and it was the extension of the Theory Reason Action (TRA) that formulated by (Fishbien \& Ajzen, 1975). TRA estimated the discrepancy between attitude and voluntary behavior and hence TPB was developed with the addition of the perceived behavioral control because behavior can be deliberative or planned. TPB proposed how the human actions are guided by predicting a particular behavior and provided behavior as intention. The TPB is the notion of the behavioral intention; a person's intention of performing a given behavior is the best predictor of whether or not the person will actually perform the behavior. It is based on the premise that the best predictor of an actual behavior is the behavior a person actually intends to do. The three variables in this model which are attitude, normative component and perceived behavior control influencing intentions and behaviors.

Motivation is the driving force that increases the desire of the human to do something in their life either catalyst by their own or other external environment. (Huitt, 2001) explained that motivation can be categorized as either intrinsic (internal to the person) or extrinsic (outside the person). This motivation theory will be grounded in this acceptance of the new cataloging standard in Malaysia. 
Intrinsic motivation is an individual behavior to do something by their own desire without hoping for any reward. (Ryan \& Deci, 2000) defined intrinsic motivation as "the innate, natural propensity to engage one's interests and exercise one's capacities, and in so doing, to seek and conquer optimal challenges". (Lee et al., 2005) refers intrinsic motivation to the fact of doing an activity for its own sake: the activity itself is interesting, engaging, or in some way satisfying. The decision to accept and use the new cataloging standard may also be partly determined by intrinsic motivation. In this research, the dimension used for the intrinsic motivation are attitude, perceive behavioral control, perceive competence, and perceive enjoyment.

(Lu et al., 2005) had been identifying attitude as a cause of intention and it is informed by beliefs as stated by (Ajzen, 1991). (Hsu \& Lin, 2008) defined attitude as the user preferences when doing activities. (Leng et al., 2011) agree that attitude has a positive influence on intention to use new things based on the (Fusilier \& Durlabhji, 2005) result that positive attitude were unaffected by other opinion. Hence, attitude can be considered as the intrinsic motivation that influences the intention to accept the new cataloging standard (RDA) in Malaysia.

Another intrinsic motivation element is Perceived Behavioral Control (PBC). (Ajzen, 1991) view $\mathrm{PBC}$ as individual beliefs and possession where it relates to an individual's performance of a certain behavior and it is determined by his or her intent to perform that behavior. (George, 2004); (Jaruwachirathanakul \& Fink, 2005); (Fusilier \& Durlabhji, 2005); (Leng et al., 2011) has examined the relationship between PBC with intention in several field within the different country setting.

Perceived Competence is one of the intrinsic motivated behavior as human need to experience competence as stated by (White, 1959) where it comes from a strong inherent need of the individual to effectively interact with their environment. (Ryan \& Deci, 2000) defined perceive competence as the perception that one is capable of producing desired outcomes and avoiding negative outcomes. Perceive competence in terms of new cataloging standard acceptance can be understood as the inherent need to feel competent with other librarian and other library as interaction to the environment where they will be intrinsically motivated to accept the new cataloging standard. This variable had been supported by other acceptance model like (Ahn, Ryu, \& Han, 2007).

The last intrinsic motivation variable in this study is Perceived Enjoyment (PE) that had been used by (Zhang, Zhao, \& Tan, 2008) and (Leng et al., 2011). (Venkatesh, 2000) define PE as the extent to which the activity of using new things is perceived to be enjoyable and fun in its own right, aside from any performance consequences resulting from the use. Several researcher had investigate the relationship between the PE with the acceptance and use of the new technology (Lee et al., 2005); (Nysveen et al., 2005); (Amin, Baba \& Muhammad, 2007; Hsu \& Lin, 2008; Leng et al., 2011). Hence, the following hypothesis was formulated:

H1: Intrinsic Motivation has a positive influence toward Librarian Intention to accept RDA.

Extrinsic motivation can be defined as the psychological energy for an activity that is based upon the contingency of an external reward which is inherently separated from the activity itself (Ryan \& Deci, 2000). (Lee et al., 2005) pertains extrinsic motivation to behaviors that are engaged in response to something apart from its own sake, such as reward or recognition or the dictates of other people. The intention to accept and use the new cataloging standard are 
determined by the extrinsic motivation variable like performance expectancy, effort expectancy, rewards and training facilitating condition.

Performance Expectancy (PE) is one of the extrinsic motivation variables as suggested by (Venkatesh, 2003). Some researcher used the term perceive usefulnes, relative advantages, outcome expectation and etc. rather than performance expectancy. Venkatesh et al (2003) and (Hsu \& Lin, 2008) defined it as the degree to which an individual believes that using the system or new things will help him or her to enhance their job performance. Perceived expectancy is a key driver of intention to accept and usage behavior usage behavior (Lee et al., 2005).

The other extrinsic motivation in this study is Effort Expectancy (EE). (Venkatesh et al., 2003) defined $E E$ as the degree of ease associated with the use of the system that is adapted from the ease of use and complexity variables. Effort expectancy is the other factor that influence the intention to accept and use the new cataloging standard in this study.

(Ryan \& Deci, 2000) recognized rewards as the extrinsic motivation and can be considered as a tool used to control human behavior as stated by (Frey \& Jegen, 2001). In this study context, rewards can be an incentive received by the librarian or its organisation when accepting and using the new cataloging standard in future.

Facilitating condition can be defined as the degree to which an individual believes that an organizational and technical infrastructure exists to support the use of the system (Venkatesh et al., 2003). They had also test the relationship between the facilitatin condition with the intention. However, in this study, facilitating condition focussed more on Training Facilitating Condition (TFC) because the implementation of the new cataloging standard need a lot of seminars and training session and involve a huge library financial. Hence,

H2: Extrinsic Motivation has a positive influence toward Librarian Intention to accept RDA.

\section{Research Methodology}

A self-administrated questionnaire was distributed and collected from librarians in NLM as a leading agency in the implementation of RDA in Malaysia. Based on the rule of thumb, the minimum number of respondents is five-to-one ratio of the number of latent variables to be tested. The questionnaire consists of four major sections. The first section gathers demographic information on the respondents such as gender, age, education, current position and cataloging standard experience while second section includes the Librarian Intention to Accept the New Cataloging Standard that adapted from (Fagan, Neill, \& Wooldridge, 2008). The third section included four sub constructs underlying intrinsic motivation as the second-order construct. The four subcontracts were attitude, perceive behavioral control, perceive competence and perceive enjoyment, adapted from previous research (Howell, 2003); (Hsu \& Lin, 2008); (Hwang, 2005); (Fusilier \& Durlabhji, 2005). The fourth part also includes four sub constructs underlying extrinsic motivation as the secondorder construct. The four subcontracts were performance expectancy, effort expectancy, rewards and training facilitating conditions, adapted from past research (Ursula et al., 2011); (Mikander, 2010); (Venkatesh et al., 2003). Table 1 in appendix indicates the items for the major construct in this study that adapted based on the Malaysian-response context. The questionnaire comprised of 36 items to measure the both dimension of intrinsic motivation and extrinsic motivation. The questionnaire with a five-point Likert scale, ranging from 1 (strongly disagree) to 5 (strongly agree) was used to collect the data. 


\section{Results And Discussion}

Purposive sampling method was used as the list of populations was not available. About 50 self-administered questionnaires were used for gathering data from the respondents in NLM. A total of 24 valid questionnaires were received by the end of data collection's period (48\% response rate). SmartPLS 2.0 software (Ringle et al., 2005) was used to evaluate the relationships among the constructs of the research model by conducting partial least squares (PLS) analysis because it allows to analyze data during the early stage of theory development (Tsang, 2002), it places minimal requirements on residual distributions and sample size to achieve a satisfactory numerical power (Hair et al., 2012) and it allows us to simultaneously evaluate both the measurement and structural model (Chin, 1998), while it eliminates concerns about the multicollinearity issues (Inkpen \& Birkenshaw, 1994). Other than that, PLS-SEM is a nonparametric approach; therefore it does not require the data to be normally distributed. However, it is important to verify that the data are not far from normal distribution. Subsequently, skewness and kurtosis were used prior to data analysis to evaluate the extent to which a variable's distribution is symmetrical (Hair et al., 2013). The skewness and kurtosis values of most items were ranged between -1 and +1 , which are well below the levels suggested for transformation of variables (Ghisseli et al., 1981). Thereby, non-normality of data is not an issue for the research. Furthermore, common method bias was assessed by conducting Harman's single factor (Podsakoff, MacKenzie, Lee, \& Podsakoff, 2003). Accordingly, single factor accounted for the majority of variance explained ( $19.14 \%$ only). This suggests that common method bias is not a major issue in this study.

\section{Demographic Profiles of Respondents}

Table 2 depicts the demographic profile of 24 respondents in NLM. The demographic profile includes the respondents' gender, age, race, highest education level, monthly salary, monthly mobile subscription, and their most recent subscription.

Table 1 Demographic profile of respondents $(n=24)$

$\begin{array}{llcc}\text { Variables } & \text { Categories } & \text { Frequency } & \text { Percentage } \\ \text { Gender } & \text { Male } & 4 & 16.7 \\ \text { Age } & \text { Female } & 20 & 83.3 \\ & \text { 26-30 years } & 5 & 20.8 \\ & \text { 31-35 years } & 8 & 33.3 \\ & \text { 36-40 years } & 7 & 29.2 \\ & \text { 41-45 years } & 1 & 4.2 \\ & \text { 46-50 years } & 2 & 8.3 \\ \text { Race } & \text { >51 years } & 1 & 4.2 \\ & \text { Malay } & 22 & 91.7 \\ \text { Education } & \text { Chinese } & 1 & 4.2 \\ & \text { Others } & 1 & 4.2 \\ \text { Current position } & \text { Diploma } & 2 & 8.3 \\ * \text { One missing value } & \text { Degree } & 18 & 75.0 \\ \text { Cataloging standard experience } & \text { Masters } & 4 & 16.7 \\ & \text { Assistant Director } & 3 & 12.5 \\ & \text { Librarian } & 17 & 70.8 \\ & \text { Assistant Librarian } & 3 & 12.5 \\ & \text { 0-5 Years } & 11 & 45.8 \\ & \text { 6-10 Years } & 8 & 33.3 \\ & \text { 11-15 Years } & 4 & 16.7 \\ & \text { >16 Year } & 1 & 4.2\end{array}$


According to Table 2, the female respondents are more than the number of male respondents with a rate of $83.3 \%$ female versus $16.7 \%$ male. The age of respondents in this category varies. In fact, about $54.1 \%$ of respondents were in the range of generation $Y$, aged between 26 and 35 years old, while $45.9 \%$ of respondents aged between 36 and above. Almost all the respondents were Malay (91.7\%), while others are Chinese and Others. The majority of respondents were professional librarian, having bachelor's degree (75.0\%) and master's $(16.7 \%)$ while only $8.3 \%$ having diploma. $12.5 \%$ of the respondents was assistant director, $70.8 \%$ was librarian while $12.5 \%$ was assistant director. Almost half of the respondents, $45.8 \%$ having a cataloging experience for less than 5 years, 33.3\% having 6 to 10 years cataloging experience, $16.7 \%$ having $11-15$ years cataloging experience and only $4.2 \%$ having cataloging experience more than 16 years.

\section{Reflective Measurement Result}

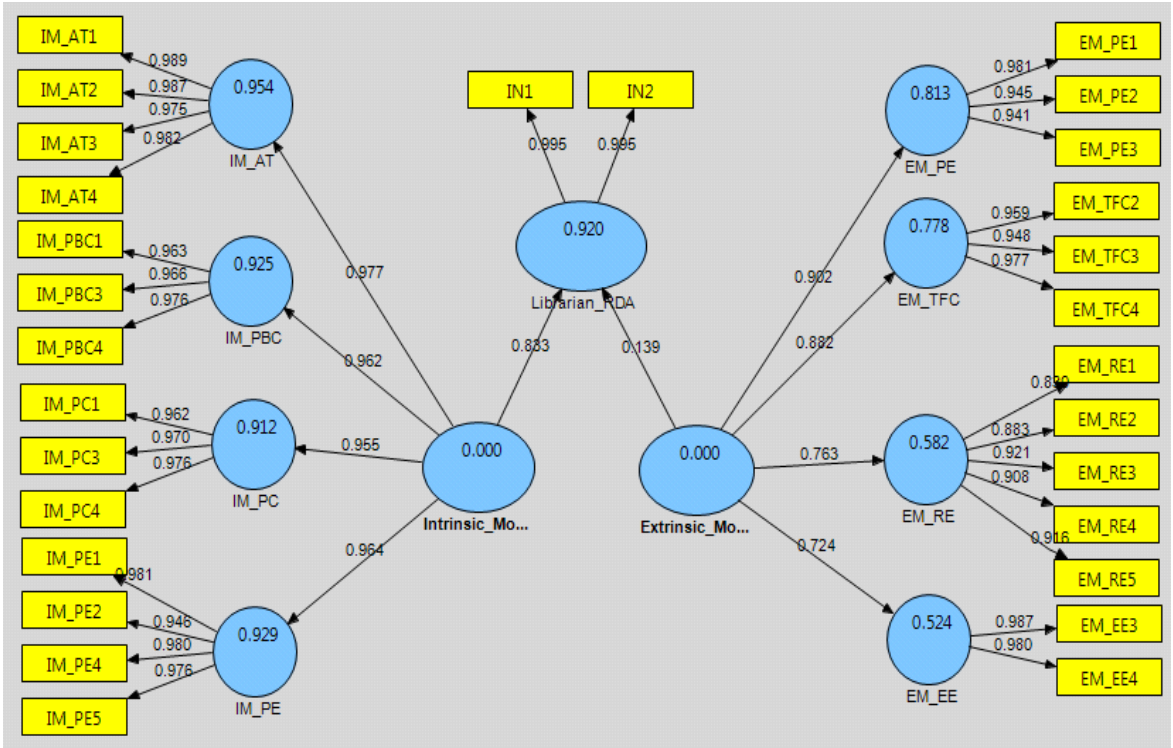

Figure 2 Measurement model

The measurement model for the reflective indicators includes composite reliability (CR) to evaluate internal consistency among items for each construct, item loading, and average extracted variance (AVE) to assess convergent validity. It also involves cross-loading and Fornell-Larcker criterion to evaluate discriminant validity among constructs in the model (Chin, 1998; Hair et al., 2013; Henseler et al., 2009).

Item loadings and reliabilities were examined to evaluate the properties of the reflective measurement models. Item loading should be 0.708 or higher that a latent variable can explain a substantial part of each indicator's variance (Hair et al., 2013). Table 3 in the appendix depicts the item loadings for all reflective measurement items which are almost above the value of 0.708 after three items (bold items) that have loadings below 0.708 were deleted as shown in Table 1. CRs for constructs were confirmed satisfactory with values above 0.70 (see Table 3) (Fornell \& Larcker, 1981). Hence, the internal consistency among the items for each construct is confirmed. Moreover, Table 3 illustrates the AVE values for each construct of the study model. AVE is well-defined as the mean value of the squared item loadings associated with the construct and an AVE value of 0.50 or higher is adequate for each construct to explain more than half of its correspondent items (Hair et al., 2013). According to Table 3, AVE values for all constructs are above 0.50 , hence it is satisfactory. 
In PLS analysis, cross-loading and Fornell-Larcker criteria need to be evaluated to confirm the discriminant validity of the reflective constructs of second-order models. First, items should load more strongly on their correspondent constructs than on other constructs. Table 4 (see Appendix) illustrates the cross-loading for the second-order constructs which shows that the main loading under each construct is higher than the cross-loading for other constructs after four italic items (see Table 1) had been drop due to the lower main loading than the crossloading for other construct.

Second, the square root of each construct's AVE should be higher than the level of correlations involving the construct (Chin, 1998). As shown in Table 5 (see Appendix), all constructs share more variance with their items (AVE) than with other constructs. Since crossloading and Fornell-Larcker criteria are met, discriminant validity among constructs of the study is confirmed.

Overall, internal reliability, convergent validity, and discriminant validity were assessed for the measurement model of the study and they are proved by conducting several statistical approaches. Therefore, we can conclude that our model has adequate validity and reliability to continue with analysis of the structural model.

\section{Structural Model Results}

This study was involved a high-order construct or hierarchical latent variable model, which there are three approach to analysis this type of model that had been summarize by Becker, Klein and Wetzels (2012). The three approaches were the repeated indicator approach (Lohmoller, 1989), the two-stage approach (Ringle et al., 2012) and the hybrid approach (Wilson \& Henseler, 2007). However this study used the two-stage approach: the Latent Variable (LV) scores are initially estimated in a model without second-order constructs (Agarwal et al., 2000). The LV scores are subsequently used as indicators in a separate higherorder structural model analysis in the second stage. The implementation is not one simultaneous PLS run.

However, prior to formative assessment of structural model, collinearity issues need to be examined between the constructs of the study. High correlations between two formative indicators can have an effect on the results as it boosts the standard error and reduces the ability to demonstrate that the estimated weights are different from zero (Hair et al., 2013). To do so, variance inflation factor (VIF) is a commonly used approach to detect multicollinearity (Petter et al., 2007). In PLS analysis, a VIF value of five and higher indicates a potential problem of collinearity (Hair et al., 2011). Based on the results of VIF tests, VIF values for all constructs were less than five which reveals no collinearity issue (see Table 6).

Table 2 Collinearity Statistics

\begin{tabular}{|l|l|}
\hline Construct & VIF \\
\hline Intrinsic Motivation & 4.927 \\
\hline Extrinsic Motivation & 4.927 \\
\hline
\end{tabular}

The results of the structural model estimates are illustrated in Table 7. The structural model was run using the bootstrap procedure by generating 5000 resamples as recommended by Hair et al (2013). According to Table 7, as the t statistics and standard error indicate, one path coefficients are significant while the other one was insignificant. In addition to path coefficient results, Figure 5 indicates the complementary evaluation tools for structural model results. Accordingly, the R2 values of endogenous constructs are illustrated for Librarian 
Intention to Accept RDA. $92.0 \%$ of variations in Librarian Intention to Accept RDA can be explained by construct of intrinsic and extrinsic motivation.

Table 3 Structural estimates

\begin{tabular}{|c|c|c|c|c|c|c|}
\hline Hypothesis & Path & & $\begin{array}{l}\text { Std. } \\
\text { Beta }\end{array}$ & $\begin{array}{l}\text { Std. } \\
\text { Error }\end{array}$ & $\begin{array}{l}\text { T- } \\
\text { value }\end{array}$ & Decision \\
\hline $\mathrm{H} 1$ & $\begin{array}{l}\text { Intrinsic } \\
\text { Motivation } \\
\text { Librarian } \\
\text { Intention } \\
\text { Accept RDA }\end{array}$ & $\rightarrow$ & 0.833 & 0.133 & 6.268 & Supported \\
\hline $\mathrm{H} 2$ & $\begin{array}{l}\text { Extrinsic } \\
\text { Motivation } \\
\text { Librarian } \\
\text { Intention } \\
\text { Accept RDA }\end{array}$ & $\rightarrow$ & 0.139 & 0.136 & 1.020 & NS \\
\hline
\end{tabular}

Stone-Geisser's Q2 for endogenous constructs are 0.897, indicating acceptable predictive relevance as their values are above zero. Overall, only one hypotheses developed in this study are supported based on the results obtained from the PLS analysis while the other one are not. In particular, based on the measurement model results, the first-order constructs of intrinsic and extrinsic motivation carried different weight.

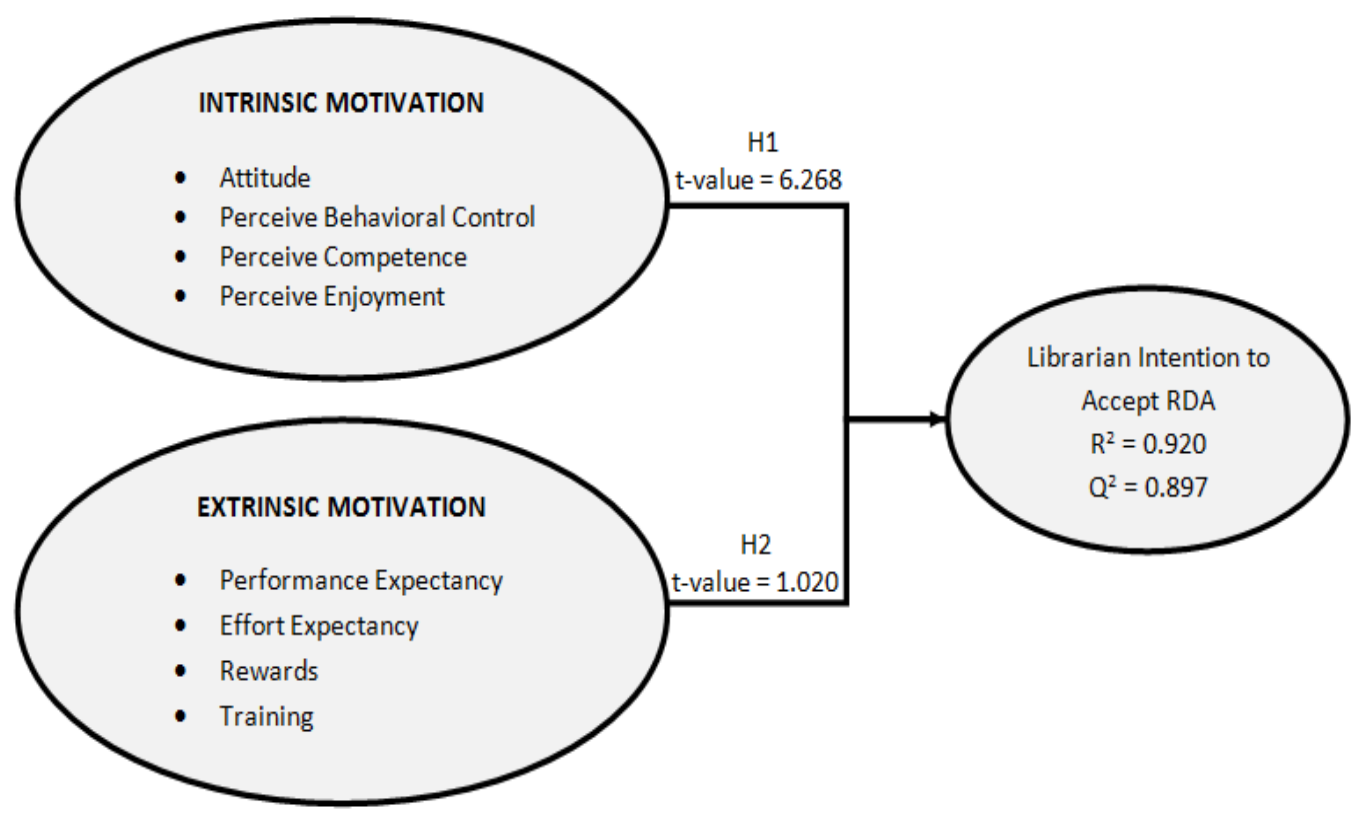

Figure 4 t-value, R2 and Q2 for the structural model

\section{Goodness of Fit}

Goodness of Fit (GoF) used to judge the overall fit of the model (Tenanhaus et al., 2005), which is the geometric mean of the average communality and the average R2 of endogenous latent variables, where comprise between measurement and the structural model respectively. The higher GoF value, the better path model estimations. GoF can be assessing by using the following formula: 
GoF $=$ VAverage R2xAverage Communality

Hence, the GoF for this study was large (0.955), where it exceeds the cut off values of 0.36 (Wetzels et al., 2009).

\section{Conclusions}

In today's dynamic information environment and changing of the cataloging standard, it is important to understand how the motivation influences the librarian intention to accept the new cataloging standard; Resource Description and Access (RDA). This is because motivation is the driving force that increases the desire of the human to do something in their life either catalyst by their own (intrinsic) or other external environment (extrinsic). The changing towards RDA in Malaysia is more intense now than ever before as the vast availability of new types of resources that available in form of digital or electronic. In Malaysia, NLM also had formulated the National Digitization Policy for Digitization of Library Materials in Malaysia and Guidelines for Digitization of Library Materials due to the changing in the information environment and resource that affect the implementation of the RDA. However, the librarian intention to accept RDA in Malaysia only influenced by the intrinsic motivation while extrinsic motivation does not influenced. This shows that, librarian in Malaysia will accept RDA for its own sake without hoping for any rewards.

\section{Acknowledgement}

Highest gratitude to Malaysian Ministry of Higher Education and Universiti Teknologi MARA (UiTM) (FRGS Research Grant (600-RMI/FRGS/ 5/3 (155/2013) and RAG Research Grant (600RMI/RAGS 5/3 (143/2013) for giving us opportunity and ample time in doing research.

\section{Corresponding Author}

Abd Latif Abdul Rahman

Faculty of Information Management Universiti Teknologi MARA Kedah 08400 Merbok

Kedah, Malaysia

Email: ablatif@uitm.edu.my

\section{References}

Abu Bakar, R., \& Jyoon, C. L. (2012). Country Report to CDNL-AO 2012. In 20th Conference on Directors of National Libraries in Asia and Oceania (CDNL-AO) (pp. 1-15).

Agarwal, R., Karahanna, E., (2000). Time Flies When You're Having Fun: Cognitive Absorption and Beliefs About Information Technology Usage. MIS Quarterly, 24 (4), 665-694.

Agrifoglio, R., Black, S., \& Metallo, C. (2010). Twitter Acceptance: The Role of Intrinsic Motivation (Vol. 10).

Ahn, T., Ryu, S., \& Han, I. (2007). The impact of Web quality and playfulness on user acceptance of online retailing. Information \& Management, 44(3), 263-275. doi:10.1016/j.im.2006.12.008

Ajzen, I. (1991). The Theory of Planned Behavior. Organizational Behaviour and Human Decisison Processes, 50, 179-211.

Amin, H., Baba, R., \& Muhammad, M. Z. (2007). An analysis of mobile banking acceptance by Malaysian customers. Sunway Academic Journal, 4. 
Becker, J. M., Klein, K., \& Wetzels, M. (2012). Hierarchical latent variable models in PLS-SEM: Guidelines for using reflective-formative type models. Long Range Planning, 45(5-6), 359-394. http://dx.doi.org/10.1016/j. Irp.2012.10.001

Chin, W. W. (1998). The partial least squares approach to structural equation modeling. In G. A. Marcoulides (Ed.), Modern methods for business research. Mahwah, NJ: Lawrence Erlbaum Associates.

Dickerson, B. J. (2013). Motivation Factors Impacting Employee Acceptance Of New Technology. Capella University.

Fagan, H., Neill, S., \& Wooldridge, B. R. (2008). Exploring The Intention To Use Computers: an empirical investigation of the role of intrinsic motivation, extrinsic motivation, and perceived ease of use. Journal of Computer Information Systems, 31-37.

Fishbien, M., \& Ajzen, I. (1975). Belief,attitude, intention and behaviour: An introduction to theory and research. Reading MA: Addision-Wasely.

Fornell, C., \& Larcker, D. F. (1981). Structural equation models with unobservable variables and measurement error: Algebra and statistics. Journal of Marketing Research, 18(3), 328-388. http://dx.doi.org/10.2307/315 0980

Frey, B. S., \& Jegen, R. (2001). Motivation Crowding Theory: A Survey of Empirical Evidence. Journal of Economic Surveys, 15(49), 589-611. Retrieved from $\mathrm{ftp}: / /$ ster.kuleuven.ac.be/incoming/eva/iewwp049.pdf

Fusilier, M., \& Durlabhji, S. (2005). An exploration of student internet use in India: the technology acceptance model and the theory of planned behaviour. Campus-Wide Information System, 22(4), 233-246. doi:10.1108/10650740510617539

George, J. F. (2004). The theory of planned behavior and Internet purchasing. Internet Research, 14(3), 198-212. doi:10.1108/10662240410542634

Ghisseli, E. E., Campell, J. P., \& Zedeck, S. (1981). Measurement theory for the behavioral sciences. San Francisco, CA: Freeman.

Hair, J. F., Ringle, C. M., \& Sarstedt, M. (2013). A primer on Partial Least Squares Structural Equation Modelling (PLS-SEM). Thousand Oaks: California SAGE Publications, Inc.

Hair, J. F., Sarstedt, M., Ringle, C. M., \& Mena, J. A. (2012). An assessment of the use of partial least squares structural equation modeling in marketing research. Journal of the Academy of Marketing Science, 40(3), 414-433. http://dx.doi.org/10.1007/s11747-0110261-6

Hair, J. F., Ringle, C. M., \& Sarstedt, M. (2011). The use of partial least squares (PLS) to address marketing management topics: From the special issue guest editors. Journal of Marketing Theory and Practice, 18(2), 135-138.

Henseler, J., Ringle, C. M., \& Sinkovics, R. R. (2009). The use of partial least squares path modeling in international marketing. In R. R. Sinkovics, \& P. N. Ghauri (Eds.), Advances in International Marketing (Vol. 20, pp. 277-320). Bingley: Emerald.

Howell, J. C. (2003). Individual Innovation Acceptance: An Intrinsic motivation Perspectives and the role of trust.

Hsu, C.-L., \& Lin, J. C.-C. (2008). Acceptance of blog usage: The roles of technology acceptance, social influence and knowledge sharing motivation. Information \& Management, 45(1), 65-74. doi:10.1016/j.im.2007.11.001

Huitt, W. (2001). Motivation to learn: An overview. Educational Psychology Interactive. Valdosta: GA: Valdosta State University. Retrieved from http://chiron.valdosta.edu/whuitt/col/motivation/motivate.html 
Hwang, Y. (2005). Investigating enterprise systems adoption: uncertainty avoidance, intrinsic motivation, and the technology acceptance model. European Journal of Information Systems, 14(2), 150-161. doi:10.1057/palgrave.ejis.3000532

Inkpen, A. C., \& Birkenshaw, J. (1994). International joint ventures and performance: An interorganizational perspective. International Business Review, 3(3), 201-217. http://dx.doi.org/ 10.1016/0969-5931(94) 90002-7

Jaruwachirathanakul, B., \& Fink, D. (2005). Internet banking adoption strategies for a developing country: the case of Thailand. Internet Research, 15(3), 295-311. doi:10.1108/10662240510602708

Jyoon, C. L., \& Zakaria, K. (2015). Resource Sharing Among Asean Libraries: Bridging The Information Divide. In The 16th ongress of Southeast Asian Libraries: ONSAL XVI (pp. 111).

Kiorgaard, D., \& Kartus, E. (2005). A rose by any other name ?: from AACR2 to Resource Description and Access. In 13th Victorian Association for Library Automation Biennial Conference. Retrieved from www.valaconf.org/vala2006/83_kartus_Final.pdf

Lee, M. K. O., Cheung, C. M. K., \& Chen, Z. (2005). Acceptance of Internet-based learning medium: the role of extrinsic and intrinsic motivation. Information \& Management, 42(8), 1095-1104. doi:10.1016/j.im.2003.10.007

Leng, G. S., Lada, S., Muhammad, M. Z., Ibrahim, A. A. A., \& Amboala, T. (2011). An Exploration of Social Networking Sites (SNS) Adoption in Malaysia Using Technology Acceptance Model (TAM), Theory of Planned Behavior (TPB) And Intrinsic Motivation. Journal of Internet Banking and Commerce, 16(2), 1-27.

Lohmöller, J.-B., 1989. Latent Variable Path Modeling with Partial Least Squares. Heidelberg: Physica-Verlag.

Lu, J., Liu, C., Yu, C.-S., \& Yao, J. E. (2005). Acceptance Of Wireless Internet Via Mobile Technology In China. Journal of International Information Management, 14(2), 117-130. Retrieved from http://scholarworks.lib.csusb.edu/cgi/viewcontent.cgi ?article=1183\&context=jiim

Mikander, C. (2010). The impact of a reward sytem on employee motivation in MotonetEspoo.

Miksa, S. D. (2009). Resource Description and Access (RDA) and New Research Potentials. American Society for Information Science and Technology, 47-51. doi:10.1002/bult.2009.1720350511

Nysveen, H., Pedersen, P. E., \& Thorbjørnsen, H. (2005). Explaining intention to use mobile chat services: moderating effects of gender. Journal of Consumer Marketing, 22(5), 247256. doi:10.1108/07363760510611671

Oliver, C. (2010). Introducing RDA: A guide to the basics. United State: American Library Association. Retrieved from http://www.alastore.ala.org/pdf/9780838998908_excerpt.pdf

Petter, S., Straub, D. \& Rai, A. (2007) Specifying Formative Constructs in Information Systems Research. MIS Quarterly, 31, 623.

Podsakoff, P. M., MacKenzie, S. B., Lee, J. Y., \& Podsakoff, N. P. (2003). Common method biases in behavioral research: A critical review of the literature and recommended remedies. Journal of Applied Psychology, 88(5),879-903. http://dx.doi.org/10. 1037/00219010.88.5.879

Ringle, C. M., Wende, S., \& Will, A. (2005). SmartPLS 2.0 (beta): www. smartpls. de. University of Hamburg. 
Ringle, C. M., Sarstedt, M., Straub, D. W. (2012). A critical look at the use of PLS-SEM in MIS Quarterly. MIS Quarterly, 36(1), III-XIV.

Ryan, R. M., \& Deci, E. L. (2000). Intrinsic and Extrinsic Motivations: Classic Definitions and New Directions. Contemporary Educational Psychology, 25(1), 54-67. doi:10.1006/ceps.1999.1020

Sánchez, R. A., \& Hueros, A. D. (2010). Motivational factors that influence the acceptance of Moodle using TAM. Computers in Human Behavior, 26(6), 1632-1640. doi:10.1016/j.chb.2010.06.011

Slot, M., \& Opree, S. J. (2021) Saying no to Facebook: Uncovering motivations to resist or reject social media platforms, The Information Society, 37 (4) 214-226

Tanuri, Z. A. M., Rahman, A. L. A., Sawal M. Z. M., Dahari, S. N. S. (2017) Modeling Librarian Acceptance Towards the New Cataloging Standard in Malaysia, Advanced Science Letters, Volume 23, Number 8, August 2017, pp. 7508-7511(4)

Tsang, E. W. K. (2002). Acquiring knowledge by foreign partners from international joint ventures in a transition economy: Learning-by-doing and learning myopia. Strategic Management Journal, 23(9), 835-854. http://dx.doi.org/10.1002/smj.251

Ursula, P. T. M., Gohar, F. K., Junghoon, M., \& Jae, J. R. (2011). E-learning motivation and educational portal acceptance in developing countries. Online Information Review, 35(1), 66-85. doi:10.1108/14684521111113597

Venkatesh, V. (2000). Determinants of perceived ease of use : Integrating control, intrinsic motivation, and emotion into the technology acceptance model. Information Systems Research, 11(4), 342-365. Retrieved from http://ocean.scihub.bz/80051e417fd042922c42262f679fe270/10.1287\%40isre.11.4.342.11872.pdf

Venkatesh, V., Morris, M. G., Davis, G. B., \& Davis, F. D. (2003). User Acceptance of Information Technology: Toward A Unified View. MIS Quarterly, 27(3), 425-478.

Wetzels, M., Odekerken-Schroder, G., \& van Oppen, C. (2009). Using PLS path modeling for assessing hierarchical construct models: Guidelines and empirical illustration. MIS Quarterly, 33(1), 177-195.

White, R. W. (1959). Motivation reconsidered: The concept of competence. Psychological Review, 66(5), 297-333. Retrieved from http://dx.doi.org/10.1037/h0040934

Wilson, B., Henseler, J. (2007). Modeling reflective higher-order constructs using three approaches with PLS path modeling: A Monte Carlo comparison. Paper presented at the Australian and New Zealand Marketing Academy Conference.

Zhang, S., Zhao, J., \& Tan, W. (2008). Extending TAM for online learning systems: An intrinsic motivation perspective. Tsinghua Science and Technology, 13(3), 312-317. doi:10.1016/S1007-0214(08)70050-6 